\title{
DUKUNGAN KELUARGA DENGAN PERAWATAN DIRI PADA PASIEN HALUSINASI
}

\author{
Tuti Sulistyaningrum ${ }^{1}$, Ayu Pratiwi ${ }^{2}$ \\ 1,2 Prodi Ilmu Keperawatan STIKes Yatsi, Tangerang \\ Jl. Aria Santika No. 40A, RT 005/RW011 Margasari, Kec. Karawaci, Kota Tangerang, \\ Banten, Indonesia \\ umitama97@gmail.com
}

\begin{abstract}
Abstrak
Pasien halusinasi kehilangan kemampuan berorientasi terhadap realita, sehingga memerlukan adanya dukungan sosial khususnya dari keluarganya untuk bisa menjalani aktifitas seperti melakukan perawatan diri. Tujuan penelitian ini untuk mengetahui hubungan antara dukungan keluarga dengan perawatan diri pasien halusinasi. Penelitian ini menggunakan desain penelitian korelasional dengan pendekatan studi cross sectional dengan sampel penelitian sebanyak 104 responden diambil dengan teknik total sampling. Pengumpulan data menggunakan alat bantu kuesioner dan analisis data yang digunakan adalah analisis univariat dan analisis bivariat menggunakan uji statistik chi square. Hasil penelitian menunjukkan bahwa gambaran pasien halusinasi di Wilayah Kerja Puskesmas Citangkil Kota Cilegon sebagian besar mendapat dukungan yang baik dari keluarganya dalam hal perawatan diri $(73,1 \%)$ dan sebagian besar memiliki perawatan diri baik $(70,2 \%)$. Terdapat hubungan antara dukungan keluarga dengan perawatan diri pada pasien halusinasi di Wilayah Kerja Puskesmas Citangkil Kota Cilegon tahun 2021 ( $\mathrm{p}$ value: 0,000).
\end{abstract}

Kata kunci : halusinasi, perawatan diri, dukungan keluarga

\begin{abstract}
Patients with hallucinations lose the ability to be oriented towards reality, so they need social support, especially from their families to be able to carry out activities such as self-care. The purpose of this study was to determine the relationship between family support and self-care of patients with hallucinations. This study uses a correlational research design with a cross sectional study approach with a research sample of 104 respondents taken by total sampling technique. Collecting data using questionnaires and data analysis used is univariate analysis and bivariate analysis using chi square statistical test. The results showed that the description of hallucinatory patients in the Cilegon City Health Center Work Area mostly received good support from their families in terms of self-care (73.1\%) and most of them had good self-care (70.2\%). There is a relationship between family support and self-care in hallucinating patients in the Cilegon City Health Center Work Area in 2021 ( $p$ value: 0.000 ).
\end{abstract}

Keywords: hallucinations, self-care, family support

\section{PENDAHULUAN}

Halusinasi adalah tanda dan gejala yang kerap muncul pada kasus gangguan kesehatan jiwa yang bisa menyebabkan berbagai masalah besar. Pada kasus halusinasi sering terjadi salah penafsiran atau salah interpretasi terhadap stimulus yang ada (Missinterpretation) (Herman, 2015).

Carolin (2017) dalam penelitiannya menyatakan bahwa halusinasi merupakan penyakit jiwa yang sering ditemukan dan perlu mendapatkan perhatian yang khusus untuk penangannya, utamanya dari keluarga. Peran serta keluarga memiliki peran utama dalam menentukan asuhan yang diperlukan pasien dirumah. Keberhasilan pengobatan di rumah sakit bisa menjadi sia-sia jika tidak dilanjutkan oleh keluarga di rumah, sehingga bisa menyebabkan kekambuhan.

Pasien dengan halusinasi bisa dipastikan tidak bisa berorientasi terhadap realita, oleh

Corresponding author:

Tuti Sulistyaningrum

umitama97@gmail.com 
sebab itu memerlukan adanya dukungan sosial khususnya dari keluarganya untuk bisa membimbing dan menjadi penyemangat dalam hidupnya. Meski demikian, tidak serta merta masalah pada penderita halusinasi selesai hanya dengan dukungan dari keluarga, namun perlu tindakan nyata dalam pemulihan jiwa dan membantu dalam pelaksanaaan perawatan diri penderita halusinasi (Afnuhazi, 2015).

Samudrra (2018) dalam penelitiannya pada pasien skizofrenia di Kecamatan Geger Kabupaten Madiun menyebutkan bahwa tingkat kemandirian perawatan diri penderita skizofrenia dipengaruhi oleh dukungan keluarganya, makin baik dukungan yang diberikan makin baik juga perawatan diri penderita skizofrenia.

Manusia memiliki berbagai kebutuhan, seperti kebutuhan fisiologis, aktualisasi diri, harga diri, rasa aman dan rasa memiliki. Kebutuhan fisiologis berkaitan dengan sistem utama dalam tubuh manusia, seperti kebutuhan udara untuk bernafas, kebutuhan nutrisi bagi tubuh, kebutuhan eliminasi serta kebutuhan perawatan diri. Sehingga jika terdapat gangguan dalam pemenuhan kebutuhan fisiologis tersebut bisa menyebabkan gangguan pada pemenuhan kebutuhan dasar lainnya (Friedman, 2014).

Kebersihan adalah sesuatu yang sangat penting dalam kehidupan yang harus diperhatikan karena bisa berpengaruh terhadap kesehatan dan psikilogis seseorang, dan bisa terpengaruh oleh nilai seseorang dan kebiasaannya. Pasien gangguan jiwa dengan halusinasi sebagian besar kurang dalam perawatan diri, hal ini salah satunya karena kurangnya dukungan keluarga terhadap perawatan diri pasien. Perawatan diri adalah kemampuan dalam merawat diri meliputi empat macam kebutuhan yakni kebutuhan mandi, kebutuhan makan, kebutuhan toilet, dan kebutuhan berpakaian (Samudrra, 2018).

Dari latar belakang dan permasalahan diatas penulis merasa tertarik melakukan penelitian dengan judul "Hubungan antara dukungan keluarga dengan perawatan diri pasien halusinasi di Wilayah Kerja Puskesmas Citangkil Kota Cilegon Tahun 2021”.

\section{METODE PENELITIAN}

Penelitian ini merupakan jenis penelitian deskriptif korelasional dengan desain penelitian cross sectional. Populasi dalam penelitian ini ialah seluruh keluarga penderita halusinasi yang berada di Wilayah Kerja Puskesmas Citangkil Kota Cilegon, yaitu sebanyak 104 orang. Teknik pengambilan sampel dalam penelitian ini menggunakan metode total sampling, yaitu dengan mengambil semua populasi yang ada.

Variabel dalam penelitian ini terdiri dari variabel independen yaitu dukungan keluarga dan variabel dependen yaitu perawatan diri penderita halusinasi. Alat pengumpulan data yang digunakan dalam penelitian ini berupa kuesioner yang terdiri dari:

1. Kuesioner dukungan keluarga, terdiri dari 20 pertanyaan dengan penilaian menggunakan skala likert dengan pilihan jawaban Selalu (SL) diberi skor 4, Sering (SR) diberi skor 3, Kadang-Kadang (KD) diberi skor 2, dan Tidak Pernah (TP) diberi skor 1.

2. Kuesioner perawatan diri penderita halusinasi, terdiri dari 10 pernyataan, setiap pernyataan diberi alternatif 2 jawaban, yaitu YA diberi nilai 1 , dan TIDAK diberi nilai 0 .

Analisis data yang digunakan adalah analisis univariat untuk mengetahui gambaran dukungan keluarga dan gambaran perawatan diri penderita halusinasi, dan analisis bivariat untuk mengetahui hubungan antara dukungan keluarga dengan perawatan diri penderita halusinasi dengan uji statistik chi square.

\section{HASIL}

\section{Hasil Analisis Univariat}

Tabel 1

Gambaran Perawatan Diri Pasien Halusinasi

\begin{tabular}{ccc}
\hline Perawatan Diri & $\begin{array}{c}\text { Jumlah } \\
(\mathbf{n})\end{array}$ & $\begin{array}{c}\text { Persentase } \\
(\mathbf{\%})\end{array}$ \\
\hline Kurang & 31 & 29,8 \\
Baik & 73 & 70,2 \\
\hline Total & $\mathbf{1 0 4}$ & $\mathbf{1 0 0}$ \\
\hline
\end{tabular}

Berdasarkan Tabel 1 diketahui bahwa dari 104 pasien halunisasi, mayoritas $(70,2 \%)$ atau sebanyak 73 pasien halusinasi memiliki perawatan diri baik.

Tabel 2

Gambaran Dukungan Keluarga

\begin{tabular}{ccc}
\hline $\begin{array}{c}\text { Dukungan } \\
\text { Keluarga }\end{array}$ & $\begin{array}{c}\text { Jumlah } \\
(\mathbf{n})\end{array}$ & $\begin{array}{c}\text { Persentase } \\
(\mathbf{\%})\end{array}$ \\
\hline Kurang & 28 & 26,9 \\
Baik & 76 & 73,1 \\
\hline Total & $\mathbf{1 0 4}$ & $\mathbf{1 0 0}$ \\
\hline
\end{tabular}


Berdasarkan Tabel 2 dapat diketahui bahwa dari 104 pasien halusinasi, mayoritas $(73,1 \%)$ atau sebanyak 76 pasien halusinasi memiliki dukungan keluarga yang baik dalam melakukan perawatan diri.

\section{Hasil Analisis Bivariat}

\section{Tabel 3}

Hubungan Dukungan Keluarga dengan Perawatan Diri Pasien Halusinasi

\begin{tabular}{|c|c|c|c|c|c|c|c|}
\hline \multirow{3}{*}{$\begin{array}{l}\text { Dukungan } \\
\text { Keluarga }\end{array}$} & \multicolumn{4}{|c|}{ Perawatan Diri } & \multirow{3}{*}{$\begin{array}{c}\text { Tot } \\
\text { al } \\
\text { n }\end{array}$} & \multirow{3}{*}{$\begin{array}{c}\text { Nilai } \\
\mathbf{p}\end{array}$} & \multirow[t]{3}{*}{ OR } \\
\hline & \multicolumn{2}{|c|}{ Kurang } & \multicolumn{2}{|c|}{ Baik } & & & \\
\hline & $\mathbf{n}$ & $\%$ & $\mathbf{n}$ & $\%$ & & & \\
\hline Kurang & 22 & 78,6 & 6 & 21,4 & 28 & 0,000 & 27,29 \\
\hline Baik & 9 & 11,8 & 67 & 88,2 & 76 & & \\
\hline Total & 31 & 29,8 & 73 & 70,2 & 104 & & \\
\hline
\end{tabular}

Berdasarkan Tabel 3 diketahui hasil uji statistik diperoleh nilai $\mathrm{p}=0,000$, sehingga bisa disimpulkan bahwa terdapat hubungan antara dukungan keluarga dengan perawatan diri pasien halusinasi. Hasil analisis juga didapatkan nilai $\mathrm{OR}=27,296$, yang berarti pasien yang kurang memiliki dukungan keluarga beresiko 27,296 kali lebih besar perawatan dirinya kurang baik dibandingkan pada pasien dengan dukungan keluarga baik.

\section{PEMBAHASAN}

\section{Gambaran Perawatan Diri Pasien Halusinasi}

Hasil penelitian menunjukan mayoritas pasien halunisasi di Wilayah Kerja Puskesmas Citangkil Kota Cilegon memiliki perawatan diri baik $(70,2 \%)$.

Herdman (2018) menjelaskan bahwa pada penderita halusinasi sering menemui hambatan dalam melakukan aktifitas sehari-hari. Pada episode psikotik dapat menjadi sangat preokupasi dengan ide-ide waham atau halusinasi, yang membuat penderita halusinasi gagal melakukan kegiatan sehari-hari. Pasien halusinasi sangat perlu bantuan dalam melakukan tugasnya sehari-hari termasuk dalam hal perawatan diri.

Hasil penelitian ini sesuai dengan hasil penelitian Herawati \& Afconneri (2020) di Kota Solok yang mendapatkan hasil sebagian besar pasien skizofrenia kebersihan dirinya baik $(62,5 \%)$, sebagian besar tampak mampu berhias diri (75\%), hampir seluruhnya tampak mampu makan (96,9\%) dan hampir seluruhnya tampak bersih setelah BAB/BAK $(96,9 \%)$.
Keliat (2011) menyebutkan bahwa tanda gejala pada pasien halusinasi yang mengalami defisit perawatan diri diantaranya yaitu, kulit kotor, berdaki dan bau, rambut kotor, kuku panjang dan kotor, gigi kotor, pakaian kotor dan tidak rapi, pakaian tidak sesuai; makan berantakan, BAK/BAB sembarangan,.

Menurut peneliti, agar penderita halusinasi dapat melakukan perawatan diri dengan baik, dan bisa berperilaku norrmal dalam masyarakat maka sangat diperlukan adanya kepedulian, dukungan dan bantuan dari keluarga serta masyarakat. Sehingga menjadi salah satu tugas dan peran serta petugas kesehatan untuk memberi pengertian kepada keluarga dan masyarakat tentang apa dan bagaimana penyakit skizofrenia tersebut, tentang bagaimana cara mengontrol perilaku klien sehingga tidak membahayakan masyarakat sekitar. Keluarga dan masyarakat yang berpikiran sempit perlu mendapat informasi yang benar serta pengetahuan tentang skizofrenia.

2. Gambaran Dukungan Keluarga Terhadap Perawatan diri Pasien Halusinasi

Hasil penelitian menunjukkan bahwa mayoritas pasien halusinasi di Wilayah Kerja Puskesmas Citangkil Kota Cilegon memiliki dukungan keluarga yang baik dalam melakukan perawatan diri $(73,1 \%)$. Hasil penelitian ini menunjukkan bahwa mayoritas keluarga (caregiver) di Wilayah Kerja Puskesmas Citangkil Kota Cilegon mendukung terhadap perawatan diri pasien halusinasi.

Dukungan keluarga merupakan proses sepanjang masa kehidupan, sifat dan jenisnya berbeda dalam seetiap tahap kehidupan. Bisa berupa dukungan sosial internal, seperti dukungan suami istri atau saudara kandung, atau dukungan keluarga eksternal dalam keluarga inti (Friedman, 2013).

Hasil penelitian ini sesuai dengan hasil penelitian Samudrra (2018) di Kecamatan Geger Kabupaten Madiun yang mendapatkan bahwa dukungan keluarga pada psien skizofrenia sebagian besar baik $(51,2 \%)$. 
Dukungan keluarga yang baik ini juga tidak terlepas dari peran serta petugas kesehatan yang rutin memberikan penyuluhan bagi keluarga (caregiver) tentang bagaimana cara merawat klien halusinasi dirumah. Petugas kesehatan membentuk kelompok Family Psycho Education yang berisi keluarga-keluarga (caregiver) yang mempunyai anggota keluarga klien halusinasi, petugas kesehatan bersama-sama keluarga berdiskusi tentang problem keluarga saat merawat klien halusinasi, bersama keluarga menyatukan persepsi dan mempraktekkan bagaimana cara merawat klien halusinasi, bersama keluarga membuat jadwal aktifitas dirumah bagi klien termasuk jadwal perawatan diri klien halusinasi.

\section{Hubungan Dukungan Keluarga dengan Perawatan Diri Pasien Halusinasi}

Hasil analisis hubungan antara dukungan keluarga dengan perawatan diri pada pasien halusinasi menunjukkan bahwa pada pasien halusinasi yang kurang memiliki dukungan keluarga, mayoritas perawatan dirinya kurang baik $(78,6 \%)$. Sedangkan pada pasien halusinasi yang memiliki dukungan keluarga baik, mayoritas perawatan dirinya baik $(88,2 \%)$.

Hasil penelitian tersebut
menggambarkan bahwa pasien halusinasi yang mendapat dukungan keluarga lebih banyak yang perawatan dirinya baik dibandingkan pada pasien halusinasi yang kurang mendapat dukungan keluarga. Hasil uji statistik diperoleh nilai $\mathrm{p}=0,000$, sehinggabisa disimpulkan ada hubungan antara dukungan keluarga dengan perawatan diri pasien halusinasi. Hasil analisis juga diperoleh nilai $\mathrm{OR}=27,296$, hal tersebut berarti bahwa pasien yang kurang memiliki dukungan keluarga beresiko 27,296 kali lebih besar perawatan dirinya kurang baik dibandingkan pada pasien yang memiliki dukungan keluarga baik.

Hasil penelitian ini sesuai dengan teori Friedman (2014) yang menjelaskan bahwa keluarga yang didalamnya terdapat seorang penderita gangguan jiwa halusinasi memiliki peran utama yaitu membantu penderita mengontrol halusinasinya dan membantu mempercepat penyembuhan pasien. Carolin (2017) juga menyatakan bahwa halusinasi perlu mendapat perhatian yang khusus dari keluarga. Keluarga memiliki peran penting dalam menentukan asuhan yang diperlukan pasien.

Hasil penelitian ini juga sesuai dengan hasil penelitian Samudrra (2018) di Kecamatan Geger Kabupaten Madiun yang mendapatkan hasil bahwa tingkat kemandirian perawatan diri penderita skizofrenia dipengaruhi oleh dukungan keluarganya. Demikian juga dengan hasil penelitian Sefrina \& Latipun (2016) di RSJ Dr. Radjiman Wediodiningrat Lawang yang menunjukkan ada kaitan erat antara dukungan keluarga dengan keberfungsian sosial pada pasien skizofrenia rawat jalan.

Friedman, (2014) menyatakan bahwa dukungan keluarga adalah support system keluarga pada anggota keluarga yang mengalami masalah. Keluarga adalah orang terdekat dan tempat yang paling nyaman bagi pasien halusinasi. Dukungan keluarga adalah sikap, tindakan dan penerimaan anggota keluarga dengan gangguan halusinasi, yang terwujud dalam bentuk kasih sayang, kehangatan, kepercayaan, perhatian, saling menghargai dan mendukung antar anggota keluarga.

Menurut peneliti, seseorang dengan gangguan halusinasi akan sulit untuk melakukan perawatan diri, hal tersebut karena pada penderita gangguan halusinasi mengalami gangguan orientasi yang menyebabkan apa yang dilihat dan dirasakan adalah sesuatu yang tidak nyata. Oleh sebab itu dalam perawatan dirinya sangat memerlukan bantuan dari orang lain, dan keluarga sebagai orang yang terdekat memiliki kewajiban untuk membantu penderita halusinasi dalam melakukan perawatan diri.

\section{KESIMPULAN}

1. Gambaran pasien halusinasi di Wilayah Kerja Puskesmas Citangkil Kota Cilegon sebagian besar mendapat dukungan yang baik dari keluarganya dalam hal perawatan diri $(73,1 \%)$ dan sebagian besar memiliki perawatan diri baik $(70,2 \%)$.

2. Ada hubungan dukungan keluarga dengan perawatan diri pada pasien halusinasi di Wilayah Kerja Puskesmas Citangkil Kota Cilegon tahun 2021 (p value: 0,000). 
Berdasar temuan dalam penelitian ini peneliti menyarankan pihak puskesmas untuk mengembangkan lagi program-program pasca perawatan pasien halusinasi dengan melibatkan keluarga sebagai caregiver dan meningkatkan sosialisasi kepada keluarga pasien untuk mengembangkan pengetahuan dan memperoleh informasi yang banyak mengenai penanganan dan perawatan pada pasien gangguan halusinasi, sehingga keluarga lebih maksimal dalam mengembalikan keberfungsian sosial pasien gangguan halusinasi.

\section{DAFTAR PUSTAKA}

Afnuhazi. (2015). Komunikasi Terapeutik Dalam Keperawatan Jiwa. Gosyen Publishing.

Carolin. (2017). Dukungan Keluarga Terhadap Kekambuhan Halusinasi Pada Pasien Skizofrenia Di Poliklik Rumah Sakit Jiwa Provinsi Sumatera Utara. Jurnal Poltekkes Kemenkes Medan.

Friedman. (2013). Keperawatan Keluarga. Gosyen Publishing.

Friedman. (2014). Buku Ajar Keperawatan Keluarga Riset, Teori \& Praktik. Jakarta : EGC.

Herawati, \& Afconneri. (2020). Perawatan Diri Pasien Skizofrenia Dengan Halusinasi. Jurnal Keperawatan Jiwa, 8, 9-20.

Herdman. (2018). NANDA International Nursing Diagnoses: definitions and classification 2018-2020. Jakarta : EGC.

Herman, A. (2015). Buku Ajar Asuhan Keperawatan Jiwa. Jakarta : EGC.

Keliat. (2011). Keperawatan Kesehatan Jiwa Komunitas CMHN (basic course). Jakarta : EGC.

Kemenkes RI. (2019). Infodatin: Situasi Kesehatan Jiwa di Indonesia.

Kementerian Kesehatan RI. (2016). Peran Keluarga Dukung Kesehatan Jiwa Masyarakat.

https://www.kemkes.go.id/article/print/16 100700005/peran-keluarga-dukung- kesehatan-jiwa-masyarakat.html

Permenkes Nomor 36 tahun 2016 tentang Program Indonesia Sehat Dengan Pendekatan Keluarga (PISPK), Pub. L. No. 36 (2016).

Permenkes nomor 4 Tahun 2019 tentang standar teknis pemenuhan mutu pelayanan dasar, (2019).

Kusnadi, J. (2018). Keperawatan Jiwa. Tangerang : Binarupa Aksara.

Potter, \& Perry. (2013). Buku ajar fundamental keperawatan: Konsep, proses dan praktik (Edisi 8). Jakarta : EGC.

Samudrra. (2018). Hubungan Dukungan keluarga dengan kemandirian Perawatan Diri pasien Skizofrenia di Kecamatan geger Kabupaten madiun. Jurnal STIKES Bhakti Husada Mulia Madiun.

Sefrina, \& Latipun. (2016). Hubungan Dukungan Keluarga dan Keberfungsian Sosial pada Pasien Skizofrenia Rawat Jalan. Jurnal Ilmiah Psikologi Terapan, 04(02), 1-21. 